\title{
Tourists' perception of deadwood in mountain forests
}

\author{
F. Pastorella, A. Avdagić, A. Čabaravdić, A. Mraković, M. Osmanović, A. Paletto
}

Pastorella F. , Avdagić A. , Čabaravdić A., Mraković A., Osmanović M., Paletto A. 2016. Tourists' perception of deadwood in mountain forests. Ann. For. Res. 59(1): 311-326.

Abstract. In traditional forest management practices, the non-living woody biomass in forests was perceived negatively. Generally, deadwood was removed during the silvicultural treatments to protect forests against fire, pests and insects' attacks. In the last decades, the perception of forest managers regarding forest deadwood is changing. However, people's opinions about the presence of deadwood in forests have been little investigated. In light of this gap, the aim of the paper is to understand tourists' perception and opinions towards deadwood in mountain forests. The survey was carried out in two study areas: the first one in Italy and the second one in Bosnia-Herzegovina. A structured questionnaire was administered to a random sample of visitors ( $n=156$ in Italy, $n=115$ in Bosnia-Herzegovina). Tourists' preferences were evaluated through a set of images characterized by a different amount of standing dead trees and lying deadwood. The collected data were statistically analyzed to highlight the preferred type of forests related to different forms of deadwood management (unmanaged forests, close-to-nature forests, extensively managed forests and intensively managed forests). The results show that both components of deadwood are perceived positively by tourists. More than $60 \%$ of respondents prefer unmanaged forests and close-to-nature managed forests, $40 \%$ of respondents prefer intensively managed forests in which deadwood is removed during the silvicultural treatments. Concerning the differences between the two study areas, a positive opinion on intensively managed forests was expressed by $40 \%$ of respondents in Italy and $22 \%$ in Bosnia-Herzegovina. Conversely, in both study areas a similar percentage of respondents preferred unmanaged forests and close-to-nature managed forests (about 40\% Genova valley and $44 \%$ in Sarajevo Canton).

Keywords forest management, lying deadwood, standing dead trees, forest recreation, people's preferences, Bosnia-Herzegovina, Italy

Authors. Fabio Pastorella (fabio.pastorella@@crea.gov.it), Council for Agricultural Research and Economics - Forest Monitoring and Planning Research Unit (CREA-MPF). Piazza Nicolini, 6 - 38123 Villazzano di Trento - Italy, - European Forest Institute (EFI) - Project Center "MOUNTFOR", via E. Mach, 138010 San Michele all'Adige (TN), Italy.; Admir Avdagić, Čabaravdić Azra, Mraković Amiina, Osmanović Merisa - University of Sarajevo, Faculty of Forestry, Sarajevo 
- Bosnia \& Herzegovina; Alessandro Paletto, Council for Agricultural Research and Economics - Forest Monitoring and Planning Research Unit (CREA-MPF), Villazano di Trento, Italy.

Manuscript received December 09, 2015; revised April 20, 2016; accepted April 27, 2016; online first May 11, 2016.

\section{Introduction}

The term deadwood refers to all non-living woody biomass not contained in the litter, either standing, lying on the ground, or in the soil, including logs, dead trunks, fallen branches, fallen twigs, dead roots and stumps (FAO 2004). According to this definition, the deadwood can be subdivided in two main components with a different ecological role in forest ecosystems (Marage \& Lemperiere 2005): standing dead trees (or snags) and lying deadwood (or logs). In addition, deadwood can be classified on the basis of size in coarse woody debris - dead woody materials with a diameter greater than 10 or $12 \mathrm{~cm}$ - and fine woody debris that is the dead woody materials with a diameter between 2.5 and 10-12 cm (Densmore et al. 2004). Generally, in several European National Forest Inventories (NFIs) the small woody materials with a diameter below 2.5 $\mathrm{cm}$ is considered as litter (Fridman \& Walheim 2000, Paletto \& Tosi 2010).

In Europe, deadwood in forest ecosystems was traditionally perceived negatively by forest managers because it was considered as an indicator of "mismanagement, negligence and wastefulness" of the applied forest management practices (Stachura et al. 2007). Consequently, in the traditional management of forests logs and snags were removed during the silvicultural treatments (i.e. thinning or final cutting) in order to protect forest ecosystems from forest fire, disasters, pests and insects' attacks (Radu 2006). Deadwood was considered to be the cause of biotic and abiotic disturbances, an obstacle to forest management activities (i.e. reforestation, logging), and threat to public safety (visitors and forest workers), so that sanitary cutting became a common activity in managed productive forest as well as in protected areas (Merganičová et al. 2012).

Over the last 80 years, forest managers' perception regarding deadwood in forests has changed (Radu 2007). The State of Europe's Forests 2011 (Forest Europe, UNECE, FAO 2011) indicates that deadwood in European forests increased over the past 20 years, varying considerably based on country, forest types, standing volume of the forest stands, decay rate and vegetation zones and that is influenced by forest management regimes (Rock et al. 2008). Besides, it indicates that the increase of deadwood in forests is furthered by policies that support a shift towards a more nature-oriented management and by forest certification standards. Besides, the scientific community has shown that deadwood is an essential element for ecological processes (Thomas 2002), a key factor in the nutrient cycling and germination of seeds (Holub et al. 2001), a fundamental element in the geomorphological and soil hydrological processes (Bragg \& Kershner 1999), a relevant carbon pool (Krankina \& Harmon 1994), a potential resource for biomass-energy (Verkerk et al. 2014), and an important habitat for many species such as cavity-nesting birds, bryophytes and saproxylic fungi (Nordén et al. 2004). Nevertheless, the relationship between deadwood and the recreational value of forests has been little investigated in the international literature; there are only few studies carried out in the urban forests in some northern European countries such as Finland and Latvia (Tyrväinen et al. 2003, Jankovska et al. 2014). Generally, in recreational forests the deadwood is removed during the silvicultural treatments because lying deadwood and standing dead trees constitutes a danger to visitors. The potential dangers caused by deadwood are manifold pollution dangerous to human health 
and a risk to the safety of visitors. Especially in urban forests deadwood on the ground is physical obstacle that can cause falls and accidents to visitors (Weidinger 2002). In addition, many forest managers think that the deadwood in recreational forests is considered by citizens sign of mismanagement, consequently they are inclined to remove it. Therefore, the key question concerning the relationship between recreational forest value and deadwood is: "What is people's perception towards this component of forests?". In order to answer this question, it is necessary to investigate the aesthetic value of forests with a special focus on the people's perception about the amount and location of deadwood in forests. The investigation of people's opinions must consider the individual preferences with regard to the visible aspects of forest management such as tree species composition, horizontal and vertical stand structure and deadwood. In the international literature, other authors have investigated people's perception towards forest stand characteristics: Tahvanainen et al. (2001) analysed the effects of different forest management activities in a recreation area of scenic beauty and recreational values in Finland; Paletto et al. (2013) investigated the local inhabitants' preferences for forest management strategies and stand characteristics in Italy; while Jankovska et al. (2014) evaluated the impact of different management activities on the landscape attributes in order to identify the preferred landscape models for recreational use according to local residents in Latvia. The individual preferences change according to the geographical context, the socio-economic conditions, local traditions (Bengston 1994, Manning et al. 1999) and they can be collected and analyzed using several techniques and tools such as questionnaire surveys, in-depth interviews, focus-group discussions, field trips, and scenario analyses (Cantiani et al. 2013). The analysis of people's preferences regarding the visible aspects of forest management may provide useful information to forest managers to better address forest management interventions in popular recreation areas. In this kind of analysis, it is particularly important to distinguish the preferences of tourists from those of local people. The information provided by tourists can be used by planners and managers in order to improve the forest areas for recreational purposes. In light of tourists' preferences, these forest areas should be managed so as to enhance the aesthetic features, e.g. tree species composition and forest age (Gundersen et al. 2006). Conversely, the preferences of local people should be included in the urban forest management plan in order to enhance visibility and attractiveness of these forest areas (De Meo et al. 2015).

Starting from these considerations, the aim of the paper is to analyse tourists' perception about the amount of standing dead trees and lying deadwood in forests. The method used to analyze tourists' preferences was applied in two study areas, one located in Italy and the other one in Bosnia-Herzegovina.

\section{Materials and methods}

\section{Study areas}

Tourists' perception regarding deadwood in forests was investigated in two study areas: the first one in the Italian Alps (Genova valley) and the second one in the Balkan Mountains in Bosnia-Herzegovina (Sarajevo Canton) (Figure 1). These study areas were chosen on the basis of the different characteristics such as destination attractiveness, tourist attendance, level of naturalness and forest management practices adopted (De Meo et al. 2015). In particular, it was decided to investigate two different forest contexts in order to collect general information not related to current forest management practices in one area.

Considering the official statistics, in Italy the average volume of deadwood (stumps, standing and lying deadwood) amounts to $8.8 \mathrm{~m}^{3} /$ ha 


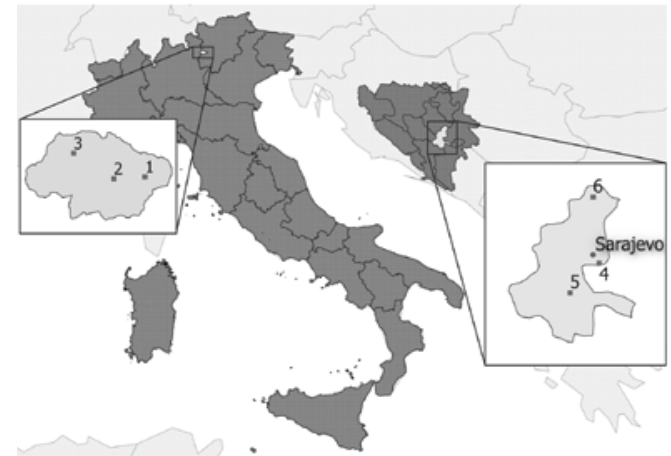

Figure 1 Study areas: Genova valley (1-3 points) and in Sarajevo Canton (4-6 points); 1 - Nardis, 2 - Ponte Maria, 3 - Bedole, 4 - Trebević, 5 - Bjelašnica and Igman, 6 - Bijambare.

(Di Cosmo et al. 2013), while in the Italian Alpine forests the deadwood volume is slightly higher (about $10.7 \mathrm{~m}^{3} /$ ha of standing dead trees and lying deadwood). In Bosnia-Herzegovina the average deadwood volume is $21.1 \mathrm{~m}^{3} / \mathrm{ha}$, but with a substantial difference between State forests $\left(25.6 \mathrm{~m}^{3} / \mathrm{ha}\right)$ and private forests $(10.9$ $\mathrm{m}^{3} / \mathrm{ha}$ ) (Vojniković et al. 2010). This difference is due to the dissimilarities in the type of forest management practices adopted by the State and private forest owners.

Genova valley. The first study area is a typical Alpine valley - the Genova valley $\left(46^{\circ} 10^{\prime} 00^{\prime \prime} \mathrm{N}, 10^{\circ} 46^{\prime} 00^{\prime \prime} \mathrm{E}\right)$ - located in the Northeast of Italy (Trentino-South Tyrol region). The Genova valley covers about 15,000 ha (approximately $60 \%$ of valley is covered by forests) and it is part of the Adamello Brenta Nature Park. The main forest types are Norway spruce (Picea abies (L.) H. Karst.) forests, pure or mixed with silver fir (Abies alba Mill.) and European larch (Larix decidua Mill.) forests. The Genova valley covers a high range of altitudes from $800 \mathrm{~m}$ a.s.l. to more than 3,000 $\mathrm{m}$ a.s.l. Due to its characteristics, the level of naturalness of the area is very high with a few scattered settlements in the lower part of the valley. The annual tourist arrivals in the Genova valley amount to around 160,000 with a prevalence of national tourists $(95 \%)$ compared to foreign tourists (5\%). The tourist flows are concentrated in the summer season because the valley is inaccessible - due to the snow - during the winter season. The forest management practices in this valley are based on the principles of close-to-nature forestry.

In the Genova valley three locations - called Nardis, Ponte Maria and Bedole - were selected because of their altitude and of their accessibility to tourists. Nardis is located in the lower part of the valley, it is easily accessible with just a few minutes' walk from the car park and it is close to an important waterfall (Nardis waterfall) that can be considered the most attractive site of the valley. Ponte Maria is in the middle part of the valley in the last accessible point by car (parking area), while Bedole is located in the high part of the valley that is accessible by public bus. Bedole is a starting point for many trekking paths that lead to the tops of the surrounding mountains.

Sarajevo Canton. The second study area is the Sarajevo Canton (4352'00" N, 18 ${ }^{\circ} 25^{\prime} 00^{\prime \prime}$ E) in Bosnia-Herzegovina. Within this area three locations were chosen. The first location (Trebevic Mountain) is in the central part of Bosnia-Herzegovina, near Sarajevo. It is a protected landscape area that covers about 440 ha and the dominant forest type is the European beech (Fagus sylvatica L.), silver fir and Norway spruce mixed forests. The second location (Bjelašnica and Igman mountains) is located in the south-western part of Sarajevo and it is characterized by many different forest types such as mountain pine (Pinus mugo Turra) forests, subalpine beech forests, European beech, silver fir and Norway spruce mixed forests. In addition, within the Bjelašnica Mountain there are virgin forest reserves which cover about 45 ha of the total area. The third location (Bijambare area) is located in the far north-eastern slopes of the Sarajevo Canton, close to the small town of Ilijaš. Bijambare is a protected area of 497 ha characterized by three main forest types: white pine (Pinus strobus L.) and Norway spruce forests, silver fir and Norway spruce forests and Norway spruce pure for- 
ests. The three locations are affected by tourist flows mainly during the summer but there are no official statistics on the exact number of tourists. During the winter season, the tourists go there to ski and to practice other winter sports, particularly on the Trebević Mountain.

\section{Survey}

In this study, tourists' visual preferences regarding deadwood in forests were collected through a questionnaire survey. A structured questionnaire was administered to a sample of tourists in both study areas. The tourists were selected in a systematic way, selecting one out of two tourists who arrived in a predetermined location such as tourist information points, car parks, starting points for nature paths, picnic and barbeque areas.

The questionnaire was structured in 32 closed-ended questions and subdivided in two thematic sections called "personal information" and "visual appeal". The questionnaire was subdivided in thematic sections in order to reduce the risk of respondents getting tired or bored (Nielsen et al. 2007).

The first thematic section focuses on the personal information of respondents (gender, age, level of education, employment and origin). Besides, in this section a question focuses on the activities carried out in mountain areas (wildlife observation, hiking, picking nonwood forest products, climbing, horseback riding, mountain biking, camping, picnicking, and hunting) by tourists. Respondents indicate the level of importance for each activity by using a 3-point Likert scale (high, medium and low level of importance) and state their personal purpose of the current visit (e.g. relax, tourism, sport, naturalness, recreation in forest).

The second thematic section considers the visual preferences on five forest stand features. The forest stand features considered in the questionnaire were the following: (1) horizontal and vertical stand structure (forests with trees of similar height and diameter; forests with trees of different height and diameter); (2) canopy cover (forests with dense and continuous foliage; open forests); (3) tree species composition (pure coniferous forests; pure broadleaved forests; mixed forests with two or more than two species); (4) spatial distribution of trees (forests with regularly distributed trees; forests with randomly distributed trees; forests with trees distributed in groups); and (5) deadwood (forests with a high proportion of logs and snags; forests with a high proportion of logs and a low proportion of snags; forests with a high proportion of snags and a low proportion of logs; forests with a low proportion of logs and snags).

Tourists' preferences on forest stand features were evaluated through a set of images able to represent a wide range of situations typical of mountain areas (Pastorella et al. 2015). Tourists indicate their preferences for each image using a 5-point Likert scale (from $1=$ =very low visual appreciation to $5=$ very high visual appreciation).

\section{Data analysis}

In this paper, only the preferences of tourists regarding one forest stand feature (i.e. deadwood) were presented and statistically analysed.

The data concerning tourists' preferences about standing dead trees and lying deadwood were analysed highlighting the differences by study area and by socio-demographic characteristics of respondents.

According to the Shapiro-Wilk test, the data collected do not follow a normal distribution both for standing dead trees ( $\mathrm{W}=0.896, p$-value $<0.0001, \alpha=0.05$ ) and for lying deadwood ( $\mathrm{W}=0.913, p$-value $<0.0001, \alpha=0.05)$. Consequently, the data were statistically compared using Mann-Whitney and Kruskal-Wallis non-parametric tests. In addition, the median is calculated for each variable considered in the analysis.

The non-parametric Mann-Whitney U test is used to compare two population means that 
come from the same population and it is based on the following three assumptions: the sample drawn from the population is random, the samples are mutually independent, and the ordinal measurement scale is assumed. In this study, the non-parametric Mann-Whitney U test was used to analyse the differences by study area and gender.

The non-parametric Kruskal-Wallis test is used when the assumptions of ANOVA are not met in order to assess significant differences on a continuous dependent variable by grouping independent variables (three or more than three groups). In this study, the non-parametric Kruskal-Wallis test was used in order to assess the differences by ranking a one-way ANOVA by age, level of education, employment and origin.

The reliability of the responses to the items related to deadwood is analysed applying a Cronbach's coefficient alpha $(\alpha)$. The test is carried out using the "alpha" function. The statistic provides an indication of the average correlation among all items that make up the scale. Values range from 0 to 1 , with higher values indicating greater reliability. It is commonly accepted that a value of 0.8 provides a reasonable reliability and that values higher than 0.6 are acceptable (Gliem \& Gliem 2003). In addition, the preferences of tourists were analyzed considering different amounts of snags and logs in the mountain forests. Particularly, the visual preferences were evaluated through a set of images showing different quantities of logs and snags in forests (Annex 1).

Starting from the individual preferences, a cluster analysis was used to identify groups of tourists with different preferences with regard to deadwood in forests. Cluster analysis is a multivariate method aimed at classifying a sample of subjects (e.g. tourists) on the basis of a set of measured variables (e.g. personal preferences) into a number of different groups so that similar subjects are placed in the same group (Everitt et al. 2001). The cluster analysis was carried out using a non-hierarchical meth316 od (or k-means clustering method). Particularly, cluster analysis segmentation was performed by the "kmeans" function set for four cluster solutions using the median to aggregate the data.

All statistical analysis was carried out using R statistical software (R Core Team, 2013).

\section{Results}

\section{Socio-demographic characteristics}

A total of 271 questionnaires were collected in the two study areas: 156 respondents in the Genova valley (response rate 73\%) and 115 in the Sarajevo Canton (response rate $80 \%$ ). The main socio-demographic characteristics of the respondents by study area are reported in Table 1.

With regard to the gender of respondents, $162(59.8 \%)$ are men and $108(40.2 \%)$ are females. The percentage of female tourists in the Genova valley is slightly higher than the one in the Sarajevo Canton (43\% to $37 \%$ ).

The level of education of respondents is quite high: $46.4 \%$ of respondents in the Genova valley and $42.9 \%$ in the Sarajevo Canton have a high school diploma whereas $36.6 \%$ in the Genova valley and $51.8 \%$ in the Sarajevo Canton have a university or post-university degree. Only the remaining $17.0 \%$ in the Genova valley and $5.4 \%$ in the Sarajevo Canton have attained elementary or secondary education.

The results concerning the employment show a great difference between the two study areas. In the Genova valley, the main categories of employment are the following ones: $25.8 \%$ of respondents are employed in the private sector, $20.6 \%$ are retired and $12.9 \%$ are professionals. By contrast, in the Sarajevo Canton the main categories of employment are distributed in the following way: $38.9 \%$ of respondents are employed in the public sector, $24.8 \%$ in the private sector and $17.7 \%$ are students.

Considering the age of respondents, the 
Table 1 Socio-demographic characteristics of respondents in Genova valley (Italy) and Sarajevo Canton (Bosnia-Herzegovina)

\begin{tabular}{|c|c|c|c|c|c|c|}
\hline \multirow{2}{*}{ Characteristics/sampling } & \multicolumn{2}{|c|}{ Genova valley } & \multicolumn{2}{|c|}{ Sarajevo Canton } & \multicolumn{2}{|c|}{ Total } \\
\hline & $\mathrm{N}$ & $\%$ & $\mathrm{~N}$ & $\%$ & $\mathrm{~N}$ & $\%$ \\
\hline Gender & & & & & 270 & \\
\hline Men & 89 & 57.4 & 73 & 63.5 & 162 & 60.0 \\
\hline Female & 66 & 42.6 & 42 & 36.5 & 108 & 40.0 \\
\hline Level of education & & & & & 265 & \\
\hline Elementary school & 5 & 3.3 & 0 & 0.0 & 5 & 1.9 \\
\hline Secondary school & 21 & 13.7 & 6 & 5.4 & 27 & 10.2 \\
\hline High school & 71 & 46.4 & 48 & 42.9 & 119 & 44.9 \\
\hline Bachelor & 12 & 7.8 & 14 & 12.5 & 26 & 9.8 \\
\hline Master & 42 & 27.5 & 40 & 35.7 & 82 & 30.9 \\
\hline PhD (doctorate) & 2 & 1.3 & 4 & 3.6 & 6 & 2.3 \\
\hline Employment & & & & & 268 & \\
\hline Dependent (public sector) & 18 & 11.6 & 44 & 38.9 & 62 & 23.1 \\
\hline Dependent (private sector) & 40 & 25.8 & 28 & 24.8 & 68 & 25.4 \\
\hline Student & 15 & 9.7 & 20 & 17.7 & 35 & 13.1 \\
\hline Businessman & 6 & 3.9 & 5 & 4.4 & 11 & 4.1 \\
\hline Teacher & 11 & 8.0 & 2 & 1.8 & 13 & 4.9 \\
\hline Researcher & 3 & 1.9 & 3 & 2.7 & 6 & 2.2 \\
\hline Housewife & 8 & 5.2 & 1 & 0.9 & 9 & 3.4 \\
\hline Professional & 20 & 12.9 & 2 & 1.8 & 22 & 8.2 \\
\hline Unoccupied & 2 & 1.4 & 4 & 3.5 & 6 & 2.2 \\
\hline Retired & 32 & 20.6 & 4 & 3.5 & 36 & 13.4 \\
\hline Age & & & & & 269 & \\
\hline$\leq 30$ years old & 21 & 13.6 & 49 & 42.6 & 70 & 26.0 \\
\hline $31-40$ years old & 17 & 11.0 & 35 & 30.4 & 52 & 19.3 \\
\hline 41-50 years old & 42 & 27.3 & 12 & 10.4 & 54 & 20.1 \\
\hline $51-60$ years old & 34 & 22.1 & 17 & 14.8 & 51 & 19.0 \\
\hline$>60$ years old & 40 & 26.0 & 2 & 1.7 & 42 & 15.6 \\
\hline Origin & & & & & 270 & \\
\hline Local tourists & 11 & 7.1 & 76 & 66.1 & 87 & 32.2 \\
\hline National tourists & 137 & 88.4 & 37 & 32.2 & 174 & 64.5 \\
\hline Foreign tourists & 7 & 4.5 & 2 & 1.7 & 9 & 3.3 \\
\hline
\end{tabular}

overall sample is equally distributed among the five classes of age considered in this study (people below 30 years old, people between 31 and 40 years old, people between 41 and 50 years old, people between 51 and 60 years old, people above 60 years old), even though there are some important differences between the two study areas. In the Sarajevo Canton $73.0 \%$ of respondents are less than 40 years old, while in the Genova valley $75.3 \%$ of respondents are more than 40 years old. Consequently, we can infer that the three touristic locations chosen in the Bosnian study area are visited mostly by young people on a one-day trip (hikers), whereas the locations in the Genova valley are preferred by more mature people. Moreover, it was found that many of the tourists in the Genova valley were there on a one-day trip as part of an itinerary in the Trentino-South Tyrol region.

As for the origin of the respondents, the results highlight the differences between the two 
study areas in terms of recreational destinations. The visitors who came from the same administrative region as the study area (the Trento province in Italy and the Sarajevo Canton in Bosnia-Herzegovina) can be considered as local tourists, while the remaining are classified as "national tourists" or "foreign tourists". In the Genova valley only $7 \%$ of respondents are local tourists, while $88 \%$ of respondents came from other parts of Italy and about 5\% from other countries. On the contrary, in the Sarajevo Canton about $66 \%$ of respondents are local tourists, while $32 \%$ came from other cantons of Bosnia-Herzegovina and only less than $2 \%$ came from other countries.

\section{Groups of tourists}

The cluster analysis has identified four groups of tourists (Table 2). The four groups are related to different types of forest management to enhance the recreational function of forests (Duncker et al. 2012). In other words, the four types of forest can be positioned in a continu$u m$ of naturalness from the natural/unmanaged forests - characterized by natural mortality of trees and a high level of naturalness - to the intensively managed forests where both lying deadwood and standing dead trees are removed for bioenergy purposes or recreational reasons (i.e. improving the accessibility to the forest or enhancing the aesthetic value of the landscape).
The first cluster of tourists (Cluster A) includes the tourists who perceive all the components of deadwood in a negative way. This kind of tourists appreciates "clean forests" where snags and logs are removed by forest management practices. In order to satisfy these tourists, deadwood should be absent or almost absent as in urban forests - where the dead trees are completely removed mainly for security/safety reasons - or in the intensively managed forests where wood residues and coarse woody debris are harvested for energy purposes (Paletto et al. 2014). In sum, it can be stated that this group of tourists prefers - probably for different personal reasons (e.g. ease of access, visual preferences, cultural reasons) - the forests managed in an intensive way.

In the second cluster (Cluster B), the tourists appreciate snags but not logs in forests. Probably, these tourists perceive standing dead trees as a relevant element for nature conservation and biodiversity protection (e.g. habitat niche for wood-breeding birds and saproxylic beetles), while deadwood on the ground is considered to be an obstacle for recreational activities (e.g. hiking, trekking, picnicking and camping). In order to satisfy these tourists, forest management practices must control the quantity of lying deadwood and remove the excess amount from forests. In particular, logs, wood residuals and dead branches on the ground should be removed in order to facilitate the accessibility to the area and to the recrea-

Table 2 Relationship between tourists' preferences about deadwood and type of forest management

\begin{tabular}{|c|c|c|c|}
\hline \multicolumn{2}{|c|}{ Perception of deadwood } & \multirow{2}{*}{ Preferred amount of deadwood in forest } & \multirow{2}{*}{ Type of forests } \\
\hline Standing & Lying & & \\
\hline - & - & $\begin{array}{l}\text { Low standing dead trees } \\
\text { Low lying deadwood }\end{array}$ & Intensive managed forests \\
\hline+ & - & $\begin{array}{l}\text { High standing dead trees } \\
\text { Low lying deadwood }\end{array}$ & Extensive managed forests \\
\hline- & + & $\begin{array}{l}\text { Low standing dead trees } \\
\text { High lying deadwood }\end{array}$ & Close-to-nature managed forests \\
\hline+ & + & $\begin{array}{l}\text { High standing dead trees } \\
\text { High lying deadwood }\end{array}$ & Natural/Unmanaged forests \\
\hline
\end{tabular}

Note. "-" indicates a negative visual appreciation, "+" indicates a positive visual appreciation. 
tional activities. In this type of forest management, big standing dead trees are preserved because they play a crucial role in maintaining natural diversity and the functioning of forest ecosystems as a wide range of plants and animals have been strongly associated with them (McComb \& Lindenmayer 1999, Marage \& Lemperiere 2005).

In the third cluster (Cluster C), the tourists appreciate the presence of logs but not of snags in forests. In order to satisfy this group of tourists, forest management practices should cut down standing dead and unhealthy trees and should reduce the removal of lying deadwood. This type of forest management requires thinning and a human impact on the forest structure but the removal of wood is limited. This type of forest management is partly based on the principles of close-to-nature management where forest stands contain a larger share of lying deadwood compared to standing dead trees (Schaich \& Plieninger 2013). The importance of preserving the lying deadwood with a large diameter (i.e. coarse woody debris) is due to the fact that this component provides important habitats for numerous insect species including flies and beetles, fungi and millipedes. Moreover, nurse logs facilitate germination of conifers in mountain forest (Vallauri et al. 2003).

The last cluster (Cluster D) includes the tourists that perceived both snags and logs in forests in a positive way. These tourists appreciate unmanaged/natural forests or managed forests where only a very small part of deadwood is removed by forest management practices. In other words, forest management practices should be very extensive or, otherwise, the forest should be managed according to the natural evolution of stand.

\section{Preferences and perceptions}

The results show that, in general, tourists perceive the presence of deadwood in forest ecosystems in a positive way (Table 3 ).
Mean values for all respondents $(n=241)$ are 2.98 for logs (median $=3$ ) and 3.30 for snags (median $=3$ ). Observing the frequency distribution of answers (Figure 2), it is possible to highlight that, concerning the presence of logs, the highest frequency of answers is "average visual appreciation" (28\% of respondents), while concerning the presence of snags, it is "high visual appreciation" (28\% of respondents). In general, respondents prefer the deadwood on the ground (logs) than standing dead trees (snags). This result is confirmed by the cluster analysis: $60 \%$ of respondents prefer forests with a high level of naturalness such as natural/unmanaged forests or close-to-nature managed forests, while the remaining $40 \%$ prefer forests which are managed in a more intensive way. Particularly, the results of the cluster analysis show that $33 \%$ of the total number of respondents prefer natural/unmanaged forests with a high presence of both deadwood components, while $29 \%$ prefer close-tonature managed forests (Table 4). In addition, $24 \%$ of respondents evaluate the presence of standing dead trees in a positive way and the presence of lying deadwood in a negative way, while the remaining $14 \%$ evaluate negatively both deadwood components. These data show that the majority of respondents prefers forests with a high level of naturalness where deadwood is considered as an integral part of the forest ecosystem.

Furthermore, tourists' perceptions were ana-

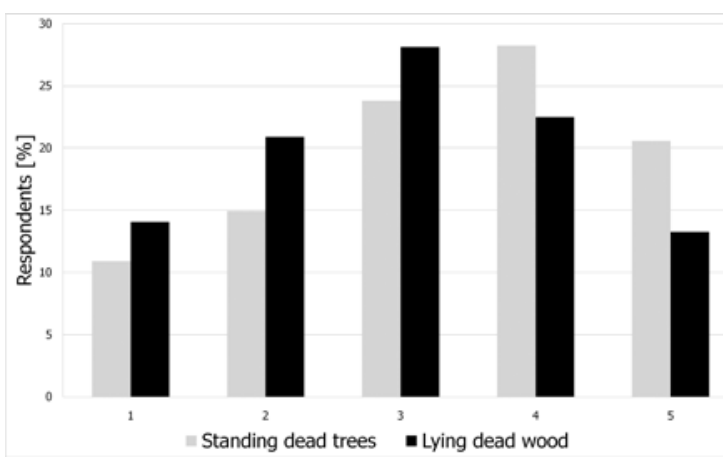

Figure 2 Frequency distribution of preferences assigned to logs and snags by tourists 
Table 3 Tourists' preferences for logs and snags by study area and socio-demographic characteristics

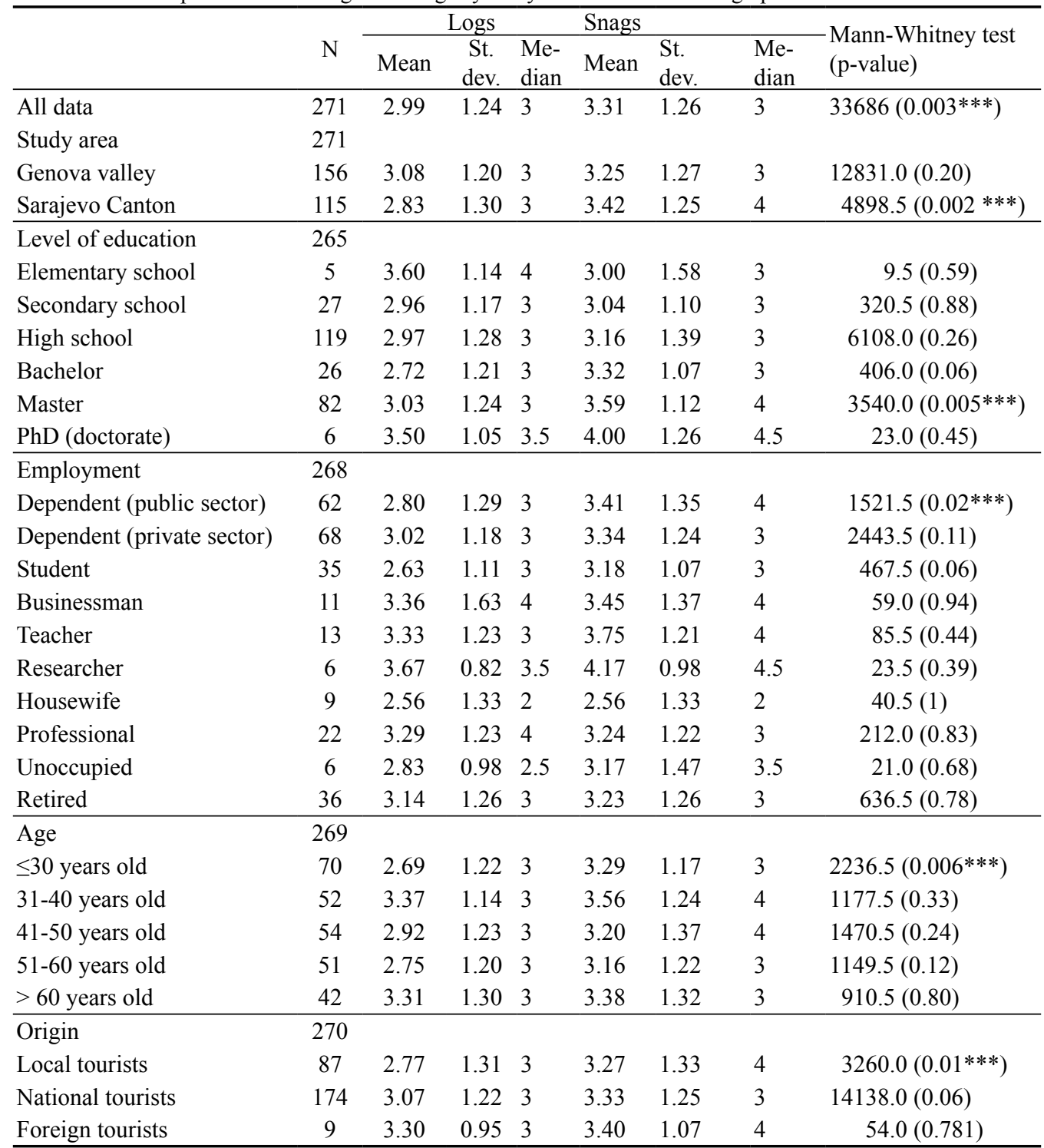

Notă. Significance: $* * * p<0.001$.

lyzed distinguishing between study area and socio-demographic characteristics of respondents (i.e. gender, level of education, job, age and origin). The knowledge of the preferences related to socio-demographic characteristics of respondents is useful in deciding forest management actions aimed at improving receptive characteristics of forests for different targets 320 (i.e. school children, families). The results show statistical differences only concerning two aspects (Table 3, 5 and 6): study area and gender. Consequently, in the following sections only the results about these two aspects will be presented and discussed.

The Crobach's alpha reliability coefficient for both lying deadwood and standing dead 
Table 4 Correspondence table of the results of the Cluster Analysis and the type of forest by the overall respondents, the study area and the gender

\begin{tabular}{lllll}
\hline Cluster & Logs & Snags & N & Type of forests \\
\hline Overall & & & & \\
\hline A & 1 & 1 & 34 & Intensive managed forests \\
\hline B & 2 & 4 & 58 & Extensive managed forests \\
\hline C & 3 & 2 & 71 & Close-to-nature managed forests \\
\hline D & 4 & 4 & 79 & Natural/Unmanaged forests \\
\hline Genova valley & 2 & 1 & 62 & Intensive managed forests \\
\hline A & 1 & 3 & 31 & Extensive managed forests \\
\hline B & 3 & 1 & 22 & Close-to-nature managed forests \\
\hline C & 4 & 5 & 39 & Natural/Unmanaged forests \\
\hline D & 1 & 1 & & \\
\hline Sarajevo Canton & & & 18 & Intensive managed forests \\
\hline A & 2 & 4 & 28 & Extensive managed forests \\
\hline B & 3 & 3 & 22 & Close-to-nature managed forests \\
\hline C & 4 & 4 & 14 & Natural/Unmanaged forests \\
\hline D & & & & \\
\hline Male & 1 & 1 & 32 & Intensive managed forests \\
\hline A & 2 & 4 & 48 & Extensive managed forests \\
\hline B & 3 & 2 & 31 & Close-to-nature managed forests \\
\hline C & 4 & 4 & 32 & Natural/Unmanaged forests \\
\hline D & & & & \\
\hline Female & 1 & 2 & 24 & Intensive managed forests \\
\hline A & 2 & 4 & 15 & Extensive managed forests \\
\hline B & 3 & 2 & 31 & Close-to-nature managed forests \\
\hline C & 4 & 29 & Natural/Unmanaged forests \\
\hline D & & &
\end{tabular}

Table 5 Kruskal-Wallis test ( $p$-value) for logs and snags perceptions by socio-demographic characteristics of respondents $(D F=$ degree of freedom $)$

\begin{tabular}{llrrr}
\hline Characteristics & $\mathrm{N}$ & DF & \multicolumn{1}{c}{ Logs } & \multicolumn{1}{c}{ Snags } \\
\hline Level of education & 265 & 5 & $3.56(0.61)$ & $7.93(0.16)$ \\
Employment & 268 & 10 & $12.47(0.25)$ & $11.33(0.33)$ \\
Age & 269 & 4 & $13.23(0.01)$ & $3.33(0.50)$ \\
Origin & 270 & 2 & $3.83(0.15)$ & $0.04(0.98)$ \\
\hline
\end{tabular}

Table 6 Kruskal-Wallis test ( $p$-value) for logs and snags perceptions by gender of respondents $(D F=$ degree of freedom)

\begin{tabular}{|c|c|c|c|c|c|c|c|c|c|}
\hline \multirow{2}{*}{ Gender } & \multirow{2}{*}{ Study areas } & \multirow{2}{*}{$\mathrm{N}$} & \multicolumn{3}{|l|}{ Logs } & \multicolumn{3}{|l|}{ Snags } & \multirow{2}{*}{$\begin{array}{l}\text { Mann-Whitney test } \\
\text { (p-value) }\end{array}$} \\
\hline & & & Mean & St.dev. & Median & Mean & St.dev. & Median & \\
\hline \multirow{3}{*}{ Male } & Genova valley & 88 & 2.97 & 1.25 & 3 & 3.23 & 1.34 & 3 & $4325.5(0.24)$ \\
\hline & Sarajevo Canton & 54 & 2.79 & 1.32 & 3 & 3.52 & 1.24 & 4 & $1998.0(0.003 * * *)$ \\
\hline & All & 162 & 2.90 & 1.28 & 3 & 3.35 & 1.30 & 4 & $12250.0(0.003 * * *)$ \\
\hline \multirow{3}{*}{ Female } & Genova valley & 66 & 3.21 & 1.12 & 3 & 3.27 & 1.18 & 3 & $2244.0(0.76)$ \\
\hline & Sarajevo Canton & 33 & 2.84 & 1.28 & 3 & 3.21 & 1.24 & 3 & $634.0(0.24)$ \\
\hline & All & 99 & 3.09 & 1.18 & 3 & 3.25 & 1.20 & 3 & $5267.5(0.35)$ \\
\hline
\end{tabular}


trees shows values between 0.68 and 0.88 . The overall coefficient for deadwood is 0.75 , while the coefficient for the Genova valley is 0.76 and that for the Sarajevo Canton is 0.74 . All the values are higher than the acceptability threshold $(\alpha=0.6)$. As the data showed an acceptable reliability, they were summed to constitute a visual indicator of forest management activities related to recreational purposes.

Considering the data by study area, it is interesting to note that in the Genova valley visitors perceive both logs (mean $=3.08$, median $=3$ ) and snags $($ mean $=3.22$, median $=3)$ in a similar way. Conversely, in the Sarajevo Canton visitors show a clear preference for snags $($ mean $=3.40$, median $=4)$ over logs $($ mean $=$ 2.81 , median $=3$ ). The non-parametric test of Mann-Whitney showed statistically significant differences in the Sarajevo Canton ( $p$-value $=$ 0.002).

According to the results of the cluster analysis, in the Genova valley $40 \%$ of tourists perceive the presence of lying deadwood and standing dead trees in forests in a negative way (Figure 3 and Table 4). On the contrary, 25\% of tourists prefer natural/unmanaged forests

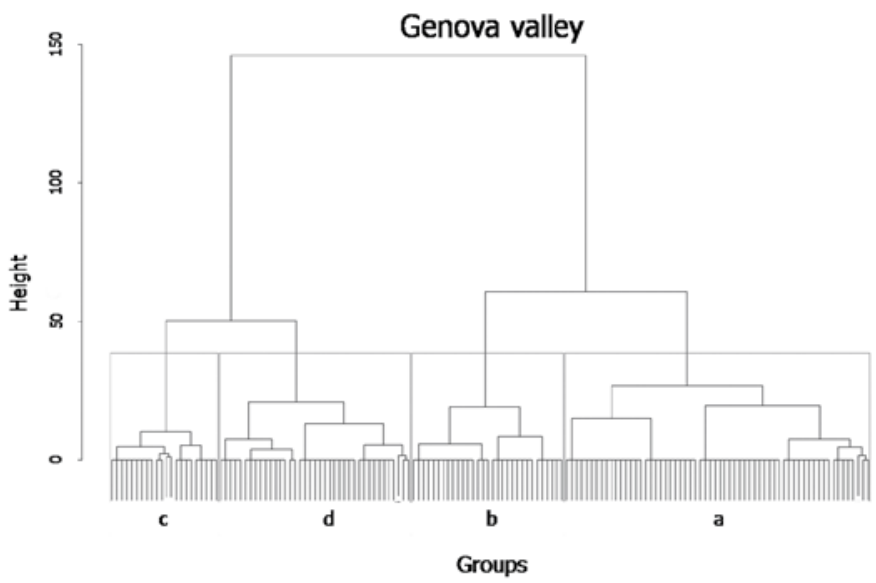

Figure 3 Dendrogram of visitors' preferences about deadwood in Genova valley's forests. The groups consist of visitors aggregated combining their perception of standing and lying deadwood: a - visitors favouring "intensive managed forests"; b - visitors favouring "extensive managed forests"; c.- visitors favouring "close-to-nature managed forests"; $\mathrm{d}$ - visitors favouring "natural/unmanaged forests" characterized by a high degree of deadwood and a low intensity of forest management. In addition, $20 \%$ of respondents indicate to prefer snags over logs, while $14 \%$ indicate a preference for close-to-nature forests where lying deadwood is not removed for ecological reasons.

Conversely, in the Sarajevo Canton the majority of tourists (34\%) evaluates positively the presence of snags and negatively the one of logs (Figure 4 and Table 4). Moreover, 22\% of respondents prefer intensively managed forests, while only $17 \%$ stated their preference for natural/unmanaged forests.

The analysis of the data by gender (Table 6) shows that females do not seem to perceive a difference between logs and snags (mean ${ }_{\text {logs }}$ $=3.09$, mean ${ }_{\text {snags }}=3.25$ ), whereas men perceive differently the two deadwood components $\left(\text { mean }_{\text {logs }}=2.90 \text {, }^{\text {mean }}{ }_{\text {snags }}=3.35\right)^{\text {. The }}$ non-parametric test of Mann-Whitney showed the existence of statistically significant differences among the male visitors in the Sarajevo Canton ( $p$-value $=0.003)$.

According to the results of the cluster analysis, most of the male visitors have a negative perception towards logs and a positive one towards snags (34\% of respondents). The remaining $66 \%$ of male respondents is equally distributed among the other three types of forests. On the contrary, the results show that female visitors view more positively forests with a high level of naturalness: $31 \%$ of female respondents prefer close-to-nature managed forests and $29 \%$ have a preference for natural/unmanaged forests.

\section{Discussion}

The study areas considered in 


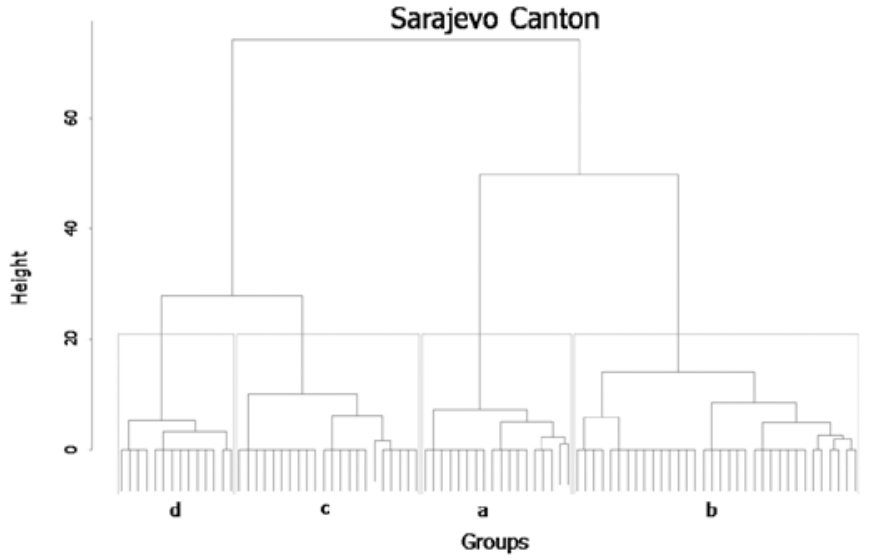

Figure 4 Dendrogram of visitors' preferences about deadwood in the Sarajevo Canton's forests. The groups consist of visitors aggregated combining their perception of standing and lying deadwood: a - visitors favouring "intensive managed forests"; b - visitors favouring "extensive managed forests"; c.- visitors favouring "close-to-nature managed forests"; d - visitors favouring "natural/unmanaged forests"

this research are characterized by significant differences in the level of naturalness, type of management and tourist attractiveness. The Genova valley is a popular recreational area during the summer season and it is mostly visited by tourists coming from all parts of Italy, while forests in the Sarajevo Canton are mainly visited by local people on a one-day trip. The comparison of the results of the two study areas shows that the cultural and geographical context affect experience and, consequently, influence personal preferences (Brown \& Daniel 1986, Brunson 1996, Edwards et al. 2012b, Hauru et al. 2014).

Edwards et al. (2012a) showed that the relationship between deadwood and forest recreational value depends on multiple factors. The experts involved in the study by Edwards et al. (2012a) highlighted that "a very low" and "a very high" volume of deadwood is seen negatively in comparison with a moderate amount. The level of respondents' knowledge about biodiversity and the relationship between coarse woody debris and biodiversity are key factors that influence the answers. Moreover, people's perception regarding deadwood is strictly re- lated to the age and the level of education of respondents: younger and more highly educated people preferred a more ecologically-oriented management than older and less-educated people. Tyrväinen et al. (2003) demonstrated that standing dead trees in a forest are generally disliked by both tourists in rural areas and visitors in urban forests. Another study carried out in the urban forests of Latvia indicated that people preferred managed forests where dead branches and deadwood were removed and human facilities were implemented (Jankovska et al. 2014). However, the authors also showed that certain groups of respondents (i.e. men) considered understorey, dead branches and deadwood in urban forests in a positive way.

According to Edwards et al. (2012b), several experts highlighted the existence of a preference for close-to-nature and low-intensity managed forests. On the contrary, Golivets (2011) found out that deadwood is one of the most important factors which contributes to create a negative attitude towards forests. Conversely, Bakhtiari et al. (2014) showed that, in the opinion of common citizens, the maintenance of ecosystem naturalness through a low level of intervention, for example by leaving deadwood in the forest, was an acceptable way of maintaining a balance in the food chain and in the nature.

The results of the present analysis confirm that multiple factors influence the relationship between deadwood and the recreational value attached to forests. Nonetheless, the results of this research are quite different compared with ones of Edwards et al. (2012a and 2012b). In this research it was found that the main factors 
that influence tourists' preferences are gender and geographical/cultural context, while the level of education, job, age and origin have a secondary importance in explaining the different perceptions. As a matter of fact, no statistically significant differences were found for these last four factors, while statistically significant differences were found for gender and study area.

To sum up these results, in the Genova valley about $40 \%$ of the visitors prefer intensively managed forests where deadwood (both logs and snags) is removed for economic or recreational purposes. On the contrary, $40 \%$ of visitors prefer forests with a higher level of naturalness (i.e. close-to-nature managed forests or the natural/unmanaged forests). In the Sarajevo Canton about $22 \%$ of visitors prefer intensively managed forests, while $44 \%$ prefer unmanaged forests or forests managed according to the principles of close-to-nature management. Hauru et al. (2014) suggested to leave logs in urban forests since it was found that logs did not affect the aesthetic experience negatively.

In addition, we can assert that gender is an important factor that influences people's perception. The results show that females prefer forests with a highest level of naturalness (natural/unmanaged forests or close-to-nature managed forests), while a high percentage of males like intensively managed forests. Probably, these differences are connected to the different values that men and females give to forests. Many studies have investigated the relationship between gender and forest values. Tarrant and Cordell (2002) demonstrated that in Southern United States, females attributed lower utilitarian values to forests than their male counterparts. In Ontario (Canada), it was found that females attached more importance to the spiritual and environmental values connected to forests, whereas males attributed a higher importance to recreational values $(\mathrm{Ku}-$ mar \& Kant 2007). Finally, Brown and Reed (2000) provided evidence that in Alaskan com- munities, economic and recreational values are more important for men while environmental and aesthetic values are of greater significance for females. These results are confirmed by a case study carried out in the Italian Alps (Paletto et al. 2012).

\section{Conclusions}

This study analysed tourists' perceptions regarding forest deadwood in mountain areas in order to provide useful information to forest managers. In forest areas characterized by a high level of attractiveness, the necessity to satisfy tourists' preferences represents an important factor to take into account when defining forest management strategies. The removal of lying deadwood during cutting operations is not always the optimal solution in forest recreation areas as the sensitivity of tourists towards environmental issues has grown in the last decades. In some circumstances, it is more appropriate to leave a fair amount of lying deadwood and dead trees in forests and to provide explanatory panels outlining the ecological role of deadwood. Awareness and information campaigns on multifunctionality of forests can lead citizens and tourists to acquire an increased knowledge about the role and importance of all components of forest ecosystems. Despite the ecological importance of deadwood in forest ecosystems, tourists' perceptions and preferences regarding this forest component has been little investigated in the international scientific literature. The main aim of this research was to overcome this gap and to stimulate the debate concerning the multifunctional role of deadwood. The amount of deadwood volume in recreational forests must be established taking into account both ecological and societal aspects in order not to compromise the functionality of ecosystems and to satisfy various forest users. The future research challenges should focus on the comparative analysis between the preferences of 
tourists and residents regarding deadwood in both urban and peri-urban forests.

\section{References}

Bakhtiari F., Jacobsen J.B., Strange N., Helles F., 2014. Revealing lay people's perceptions of forest biodiversity value components and their application in valuation method. Global Ecology and Conservation 1: 27-42. DOI: 10.1016/j.gecco.2014.07.003

Bengston D.N., 1994. Changing forest values and ecosystem management. Society \& Natural Resources 7: 515533. DOI: $10.1080 / 08941929409380885$

Bragg D.C., Kershner J.L., 1999. Coarse Woody Debris in Riparian Zones. Journal of Forestry 4: 30-35.

Brown G., Reed P., 2000. Validation of a Forest Values Typology for Use in National Forest Planning. Forest Science 46: 240-247.

Brown T.C., Daniel T.C., 1986. Predicting scenic beauty of timber stands. Forest Science 32: 471-487.

Brunson M.W., 1996. A definition of "social acceptability" in ecosystem management. In Brunson M.W., Kruger L. E., Tyler C.B., Schroeder S.A., (eds.), Defining social acceptability in ecosystem management: A workshop proceedings, USDA For. Serv., Gen. Tech. Rep. PNW369, pp. 7-17.

Cantiani M.G., De Meo I., Paletto A., 2013. What do Human Values and Emotions Suggest about Forest Planning? An International Review Focusing on the Alpine Region. International Review of Social Sciences and Humanities 6(1): 228-243.

De Meo I., Paletto A., Cantiani M.G., 2015. The attractiveness of forests: preferences and perceptions in a mountain community in Italy. Annals of Forest Research 58: 145-156. DOI: $10.15287 /$ afr.2015.308

Densmore N., Parminter J., Stevens V., 2004. Corse woody debris: Inventory, decay modelling, and management implications in three biogeoclimatic zones. Journal of Ecosystems Management 2: 14-29.

Di Cosmo L., Gasparini P., Paletto A., Nocetti M., 2013. Deadwood basic density values for national-level carbon stock estimates in Italy. Forest Ecology and Management 295: 51-58. DOI: 10.1016/j.foreco.2013.01.010

Duncker P.S., Barreiro S.M., Hengeveld G.M., Lind T., Mason W.L., Ambrozy S., Spiecker H., 2012. Classification of Forest Management Approaches: A New Conceptual Framework and Its Applicability to European Forestry. Ecology and Society 17: 50-66. DOI: 10.5751/ ES-05262-170451

Edwards D.M., Jay M., Jensen F.S., Lucas B., Marzano M., Montagné C., Peace A., Weiss G., 2012a. Public preferences across Europe for different forest stand types as sites for recreation. Ecology and Society 17: 27-37. DOI: 10.5751/ES-04520-170127

Edwards D.M., Jay M., Jensen F.S., Lucas B., Marzano M., Montagné C., Peace A., Weiss G., 2012b. Public preferences for structural attributes of forests: Towards a pan-European perspective. Forest Policy and Economics 19: 12-19. DOI: 10.1016/j.forpol.2011.07.006

European Environment Agency, 2014. Developing a forest naturalness indicator for Europe. Concept and methodology for a high nature value (HNV) forest indicator. EEA Technical report 13/2014, Luxembourg.

Everitt B.S., Landau S., Leese M., 2001. Cluster Analysis. Arnold, London.

FAO, 2004. Global Forest Resources Assessment Update 2005: Terms and definitions. Working Papers 83/E. Forest Resources Assessment Programme, Rome.

Forest Europe, UNECE, FAO, 2011. State of Europe's Forests 2011. Status and Trends in Sustainable Forest Management in Europe, Oslo.

Fridman J., Walheim M., 2000. Amount, structure, and dynamics of dead wood on managed forestland in Sweden. Forest Ecology and Management 131: 23-36. DOI: 10.1016/S0378-1127(99)00208-X

Gliem J.A., Gliem R.R., 2003. Calculating, Interpreting, and Reporting Cronbach's Alpha Reliability Coefficient for Likert-Type Scales. Midwest Research to Practice Conference in Adult Continuing and Community Education, pp. 82-88.

Golivets M., 2011. Aesthetic Values of Forest Landscapes. Master thesis, Swedish University of Agricultural Sciences.

Gundersen V., Frivold L.H., Myking T., Øyen B.H., 2006. Management of urban recreational woodlands: The case of Norway. Urban Forestry \& Urban Greening 5: 73-82. DOI: 10.1016/j.ufug.2006.06.003

Hauru K., Koskinen S., Kotze D.J., Lehvävirta S., 2014. The effects of decaying logs on the aesthetic experience and acceptability of urban forests - Implications for forest management. Landscape and Urban Planning 123: 114-123. DOI: 10.1016/j.landurbplan.2013.12.014

Holub S.M., Spears J.D.H., Lajtha K., 2001. A reanalysis of nutrient dynamics in coniferous coarse woody debris. Canadian Journal of Forest Research 31: 1894-1902. DOI: $10.1139 / \mathrm{x} 01-125$

Jankovska I., Straupe I., Brumelis G., Donis J., Kupfere L., 2014. Urban forests of Riga, Latvia - Pressures, Naturalness, Attitudes and Management. Baltic Forestry $20(2): 342-351$.

Krankina O.N., Harmon M.E., 1994. The impact of intensive forest management on carbon stores in forest ecosystems. World Resource Review 6: 161-177.

Kumar S., Kant S., 2007. Exploded logit modeling of stakeholders' preferences for multiple forest values. Forest Policy and Economics 9: 516-526. DOI: 10.1016/j.forpol.2006.03.001

Manning R., Valliere W., Minteer B., 1999. Values, ethics, and attitudes toward national forest management: an empirical study. Society \& Natural Resources 12(5): 421-436. DOI: 10.1080/089419299279515

Marage D., Lemperiere G., 2005. The management of snags: A comparison in managed and unmanaged ancient forests of the Southern French Alps. Annals of Forest Science 62: 135-142. DOI: 10.1051/forest:2005005

McComb W., Lindenmayer D., 1999. Dying, dead, and down trees. In Hunter M.L. (ed.), Maintaining biodiversity in forest ecosystems, Cambrige Univer- 
sity Press, Cambrige, pp. 335-361. DOI: 10.1017/ CBO9780511613029.012

Merganičová K., Merganič J., Svoboda M., Bače R., Šebeň V., 2012. Deadwood in forest ecosystems. In Blanco J.A., Lo Y.H. (eds.), Forest Ecosystems More than Just Trees, InTech Book, pp. 81-108. DOI: $10.5772 / 31003$

Nielsen A.B., Olsenb S.B., Lundhede T., 2007. An economic valuation of the recreational benefits associated with nature-based forest management practices. Landscape and Urban Planning 80: 63-71.

DOI: 10.1016/j.landurbplan.2006.06.003

Nordén B., Ryberg M., Götmark F., Olausson B., 2004. Relative importance of coarse and fine woody debris for the diversity of wood-inhabiting fungi in temperate broadleaf forests. Biological Conservation 117: 1-10. DOI: 10.1016/S0006-3207(03)00235-0

Paletto A., De Meo I., Cantiani M.G., Maino F., 2013. Social Perceptions and Forest Management Strategies in an Italian Alpine Community. Mountain Research and Development 33(2): 152-160. DOI: 10.1659/ MRD-JOURNAL-D-12-00115.1

Paletto A., De Meo I., Cantiani P., Ferretti F., 2014. Effects of forest management on the amount of deadwood in Mediterranean oak ecosystems. Annals of Forest Science 71: 791-800. DOI: 10.1007/s13595-014-0377-1

Paletto A., Maino F., De Meo I., Ferretti F., 2012. Perception of Forest Values in the Alpine Community of Trentino Region (Italy). Environmental Management 8: 414-422.

Paletto A., Tosi V., 2010. Deadwood density variation with decay class in seven tree species of the Italian Alps. Scandinavian Journal of Forest Research 25: 164-173. DOI: $10.1080 / 02827581003730773$

Pastorella F., Paletto A., 2015. Tourists' perception and preferences regarding deadwood in forest. Conference paper of "Mountain Forest Management in a Changing World”, 7-9 July 2015, High Tatra Mountains, Slovakia. DOI: 10.13140/RG.2.1.3545.1289

R Core Team, 2013. R: A language and environment for statistical computing. R Foundation for Statistical Computing, Vienna, Austria. URL http://www.R-project. org/. Accessed 28 May 2015.

Radu S., 2006. The ecological role of deadwood in natural forests. Environmental Engineering Science 3: 137141. DOI: $10.1007 / 978-3-540-47229-2 \_16$

Radu S., 2007. The ecological role of deadwood in natural forests. In Gafta D., Akeroyd J., (eds.) Nature Conservation: Concepts and Practice, Springer Verlag, Berlin.

Rock J., Badeck F.W., Harmon M.E., 2008. Estimating decomposition rate constants for European tree species from literature sources. European Journal of Forest Research 127: 301-313. DOI: 10.1007/s10342-008-0206-x

Schaich H., Plieninger T., 2013. Land ownership drives stand structure and carbon storage of deciduous temperate forests. Forest Ecology and Management 305: 146-157. DOI: 10.1016/j.foreco.2013.05.013

Stachura K., Bobiec A., Obidzi-ski A., Oklejewicz K., Wolkowycki D., 2007. Old trees and decaying wood in forest ecosystems of Poland, "Old Wood". A toolkit for participants, Version 07. oldwood.eu.interiowo.pl/ OW 07.pdf. Accessed 28 May 2015.

Tahvanainen L., Tyrväinen L., Ihalainen M., Vuorela N., Kolehmainen O., 2001. Forest management and public perceptions - visual versus verbal information. Landscape and Urban Plannng 53: 53-70. DOI: 10.1016/ S0169-2046(00)00137-7

Tarrant M.A., Cordell H.K., 2002. Amenity Values of Public and Private Forests: Examining the Value-Attitude Relationship. Environmental Management 30: 692-703. DOI: $10.1007 / \mathrm{s} 00267-002-2722-7$

Thomas J.W., 2002. Dead Wood: from Forester's Bane to Environmental Boon. In Laudenslayer W.F. Jr, Shea P.J., Valentine B.E., Weatherspoon C.P., Lisle T.E. (eds.), Ecology and Management of Deadwood in Western Forests. Reno, NV. USDA Forest Service General Technical Report PSW-GTR-181, pp. 3-9.

Tyrväinen L., Silvennoinen H., Kolehmainen O., 2003. Ecological and aesthetic values in urban forest management. Urban Forestry \& Urban Greening 1: 135-149. DOI: $10.1078 / 1618-8667-00014$

Vallauri D., André J., Blondel J., 2003. Le bois mort, une lacune des forêt gérérs. Revue forestière française 2: 99-112.

Verkerk P.J., Mavsar R., Giergiczny M., Lindner M., Edwards D., Schelhaas M.J., 2014. Assessing impacts of intensified biomass production and biodiversity protection on ecosystem services provided by European forests. Ecosystem Services 9: 155-165. DOI: 10.1016/j. ecoser.2014.06.004

Vojniković S., Višnjić Ć., Balić B., 2010. Second National Forest Inventory in Bosnia and Herzegovina (2006-2009). Preliminary data. Federalno ministarstvo poljoprivrede, vodoprivrede i šumarstva Ministarstvo poljoprivrede, šumarstva i vodoprivrede Republike Srpske.

Weidinger H., 2002. Recreational forest management: Sustainably protecting and improving the recreational function of the Vienna woods. In: Arnberger A., Brandenburg C., Muhar A. (eds.), Conference proceedings "Monitoring and management of visitor flows in recreational and protected areas", pp. 302-330. 